\title{
The Americans with Disabilities Act 25th Anniversary: Assessing Progress, Opportunities, and Challenges
}

\author{
John Grady and Anita M. Moorman \\ Guest Editors
}

The Americans with Disabilities Act (ADA) is one of the most comprehensive pieces of civil rights legislation that prohibits discrimination and guarantees that people with disabilities have opportunities equal to everyone else to participate in mainstream American life. The origins of the ADA began during the 1960s Civil Rights movement. While the Civil Rights Act of 1964 prohibited discrimination on the basis of race, religion, and national origin, the law did not protect people with disabilities. Discrimination on the basis of disability would first be addressed in 1973 with the enactment of Section 504 of the Rehabilitation Act of 1973. Section 504 was limited in its scope by not protecting people with disabilities from discrimination in employment or public accommodations in the private sector. Not until passage of the ADA in 1990 were comprehensive protections provided for people with disabilities in the United States.

Reflecting on the progress made over the past 25 years, the ADA has transformed sport and recreation in multiple areas, several of which are specifically examined in articles featured in this Special Issue. The articles that follow help to highlight ADA's impact related to (1) facilities and events, (2) participation opportunities in sport and recreation, and (3) policy development and management of sport and recreation organizations. Each article featured in this Special Issue examines the role and impact the ADA has had or may have in the future to provide greater access and opportunity in sport and recreation. In their article about perceptions and attitudes of elite athletes with disabilities, Cottingham et al. examine the athletes' perspective of accessibility before and after passage of the ADA. Meanwhile, Young et al. analyze whether Big Ten campus recreation programs provide a welcoming environment through information provided on their websites. Hums et al. present universal design as an effective management strategy in tandem with ADA requirements to benefit those with and without disabilities in society. Finally, Gillentine et al. predict how the ADA may be applied in the near future to create accessible and safe tailgating for people with disabilities and older fans.

Grady (jgrady@sc.edu) is with the Dept. of Sport and Entertainment Management, University of South Carolina, Columbia, SC. Moorman (amm@louisville.edu) is with the Sport Administration Program, University of Louisville, Louisville, KY. They are Guest Editors for this special issue of the Journal of Legal Aspects of Sport. 


\section{Overview of ADA Legal and Policy Issues}

The ADA is viewed as the most influential piece of legislation for people with disabilities. It marked a paradigm shift in North American disability law and helped shape global approaches to disability rights and public access to stadia (Grady \& Paramio, 2012; Paramio, Campos, \& Buraimo, 2012). Legal and policy issues involving the ADA's impact in the sport industry cover a broad spectrum (Moorman, 2010), including the following areas.

\section{Sport Facilities and Events}

Perhaps no segment of the sport industry has been impacted more by the ADA's technical requirements than the sport venue industry. Mingus (2004) opined that the ADA "has been a revolution of sorts" which has caused "the shape of our facilities and the way we execute our events [to] never be the same" (p. 15). "Despite the clear mandate to guarantee access, the complex and often ambiguous patchwork of federal laws, regulations, and guidelines has left many venue managers scratching their heads trying to figure out how best to achieve compliance" (Grady \& Carpenter, 2007, p. 7). Legal disputes involving stadium design and construction have raised a number of issues over the years, including the number of required wheelchair accessible seats, the placement of those seating locations, and the availability of equivalent sightlines (McArdle, 2009). With the benefit of technical assistance and best practice recommendations, as well as ongoing professional training provided by industry trade organizations, today's sport facility managers now find innovative ways to accommodate spectators with disabilities. ADA compliance has become so well ingrained into the facility management culture that managers seamlessly integrate these requirements into their standard operating procedures (Grady, 2005).

\section{Participation Opportunities and Sport Rules}

While the U.S. Department of Justice provides specific guidance for accessible stadiums, it does not provide detailed guidelines for sport organizations in designing and operating their sports and recreation programs relative to participation opportunities. Thus, the legal framework for analyzing disputes related to participation opportunities has been created by the courts on a case-by-case basis (Anderson, 2002; Moorman, 2010). The U.S. Supreme Court first reviewed the ADA in sport in the landmark case PGA Tour, Inc. v. Martin (2001). In Martin, the Court affirmed a key component of the statutory framework of the ADA to require providers of programs and services to make reasonable modifications of policies and practices for people with disabilities. A central element of both competition rules and eligibility rules cases surrounds a determination of what does or does not amount to a "fundamental alteration" of the sport, activity, or program in question (Stone, 2007). Martin affirmed the legal analysis used by many lower courts that included the requirement to conduct an individualized inquiry of the requested modification to evaluate the reasonableness of the request. Martin also served as an important reminder that the ADA is not limited to the physically accessible design features of stadia and arenas, but instead applies broadly to all policies and practices of a sport organization, including eligibility and competition rules (Masteralexis \& Moorman, 2001). 


\section{Policy Development and Inclusion}

Lastly, many sport organizations have recognized both their legal and ethical obligation to address disability discrimination through proactive policy development rather than in response to litigation (ECAC, 2015; Hendrickson, 2013; Hums, Moorman, \& Wolff, 2003; Olmstead, 2015). However, litigation can also prompt sport organizations to review and update policies and procedures to be more inclusive organizations. For example, even though Scot Hollonbeck's suit against the U.S. Olympic Committee (Hollonbeck v. United States Olympic Committee, 2008) under both Section 504 and the ADA was unsuccessful in compelling benefits for Paralympic athletes similar to those provided Olympic athletes, it produced the necessary environment to engage Olympic and Paralympic stakeholders to implement new policies and practices to provide for more equal development of Paralympic sports and athletes (Legg, Fay, Wolff, \& Hums, 2015).

\section{Future Challenges and Opportunities}

Today, the global popularity of sport - and the physical, social, and economic developmental benefits derived from it - make it an ideal mechanism for fostering the inclusion and well-being of people with disabilities (United Nations, 2011). Compared to other customer-centric organizations, however, full inclusion of people with disabilities in many aspects of sport and recreation has yet to be achieved. For example, the cultural arts have far outpaced the progress seen in the sport industry by consistently going beyond the law's minimum requirements in order to create a truly accessible and welcoming customer experience (National Endowment for the Arts, 2010). These organizations have strategically embraced customers with disabilities as a new untapped market while still being mindful of patron safety and security issues (Paramio-Salcines, Grady, \& Downs, 2014). Rather than being seen as a leader in this area, many segments of the sport industry still seem hesitant to fully embrace inclusive principles. Instead of waiting for proactive plaintiffs and their legal teams to test the boundaries of the ADA with novel legal claims, sport and recreation managers should work to achieve full and equal inclusion of employees, athletes, patrons, and spectators. An inclusive and accessible sport environment extends opportunities not only for people with disabilities, but all those who may benefit from improved access, thereby promoting both the letter and spirit of the ADA. The sport and recreation industry must continue to work proactively and deliberately to respond to a growing call to provide meaningful access to their events, venues, and programs.

\section{References}

Anderson, P.M. (2002). A cart that accommodates: Using case law to understand the ADA, Sports, and Casey Martin. Virginia Sports and Entertainment Law Journal, 1, 211-256.

Eastern College Athletic Conference. (2015, January 22). ECAC Board of Directors cast historic vote to add varsity sports opportunities for student-athletes with disabilities in ECAC leagues and championships. ECACsports.com. Retrieved http://www. ecacsports.com/news/2014-15/sports_opportunities_for_student-athletes_with_disabilities_in_ECAC_leagues_and_championships 
Grady, J. (2005). The Americans with Disabilities Act: Past, present, and future challenges for sport and entertainment facility managers. Proceedings of the International Association of Assembly Managers (IAAM) Conference.

Grady, J. \& Carpenter, J.C. (2007). Teaching sport and entertainment venue managers about ADA compliance: Implications for staff training. Proceedings of the 2007 International Conference on Sport and Entertainment Business (ICSEB), 7-22.

Grady, J. \& Paramio, J. (2012). Global approaches to managing the fan experience for patrons with disabilities. Sport Marketing Association Conference: Orlando, FL.

Hendrickson, B. (2013, May 7). Institutional role in providing for disabled athletes discussed. NCAA.org. Retrieved http://www.ncaa.org/about/resources/media-center/news/ institutional-role-providing-disabled-athletes-discussed

Hollonbeck v. United States Olympic Committee, 513 F.3d 1191 (10 ${ }^{\text {th }}$ Cir. 2008).

Hums, M.A., Moorman, A.M., \& Wolff, E.A. (2003). The inclusion of the Paralympics in the Olympic and Amateur Sports Act: Legal and policy implications for integration of athletes with disabilities into the USOC and national governing bodies. Journal of Sport and Social Issues, 27(3), 261-275.

Legg, D., Fay, T., Wolff, E.A., \& Hums, M. (2015). The International Olympic CommitteeInternational Paralympic Committee relationship: Past, present, and future. Journal of Sport and Social Issues, 39(5), 371-395.

Masteralexis, L.P., \& Moorman, A.M. (2001, June 11). PGA-Martin's ruling's a verdict for inclusion, not doom. Street \& Smith's Sports Business Journal. Retrieved http://www. sportsbusinessdaily.com/Journal/Issues/2001/06/20010611/No-Topic-Name/PGAMartin-Rulings-A-Verdict-For-Inclusion-Not-Doom.aspx

McArdle, D. (2009). Using the Americans with Disabilities Act to inform "access to sporting venues" under the disabilities Convention. Boston University International Law Journal, 27(2), 317-344.

Mingus, M. (2004). The ADA: Does your facility demonstrate "good faith progress" towards compliance. Facility Manager, 14-15.

Moorman, A.M. (2010, June). The impact of the ADA on sport competition and eligibility rules: A compliance model for sport organizations. Presentation at the North American Society for Sport Management Conference: Tampa, Florida. Retrieved from https:// www.nassm.com/files/conf_abstracts/2010-087.pdf

National Endowment for the Arts. (2010). 2010 Revised regulations of the Americans with Disabilities Act Titles II and III. Arts.gov. Retrieved from https://www.arts.gov/sites/ default/files/NEA-ADA-TipSheet-v2.pdf

Olmstead, M. (2015, July 30). 25 years of the Americans with Disabilities Act: How the ADA continues to impact athletes competing today. Women's Sport Foundation. Retrieved from http://www.womenssportsfoundation.org/home/she-network/sports/25-years-ofthe-americans-with-disabilities-act-how-the-ada-continues-to-impact-athletes

Paramio, J.L. Campos, C. \& Buraimo, B. (2012). Promoting accessibility for fans with disabilities to European stadiums and arenas: A holistic journey sequence approach. In L. Trenberth \& D. Hassan (Eds.), Managing sport business: An introduction. London: Routledge, pp. 367-388.

Paramio-Salcines, J., Grady, J. \& Downs, P. (2014). Growing the football game: The increasing economic and social relevance of older fans and those with disabilities in the European football industry. Soccer and Society, 15(6), 864-882.

PGA Tour, Inc. v. Martin, 532 U.S. 661 (2001).

Stone, K.L. (2007). The politics of deference and inclusion: Toward a uniform framework for analysis of "fundamental alteration" under the ADA. Hastings Law Journal, 58, 1241-1295.

United Nations. (2011, June 27). Panel discussion on sports for inclusive development. UN.org. Retrieved http://www.un.org/disabilities/default.asp?id=1574 